\title{
Presence of auxin indole-3-acetic acid in the northern Adriatic Sea: phytohormones and mucilage
}

\author{
H. Mazur ${ }^{1}$, E. Homme ${ }^{2}$ \\ ${ }^{1}$ Department of Plant Physiology, University of Gdansk, 81-378 Gdynia, Poland \\ ${ }^{2}$ ECP EniChem Polimeri, I-30175 Porto Marghera (VE), Italy
}

\begin{abstract}
High-performance liquid chromatography and combined gas chromatography - mass spectrometry were used to study the presence of indole-3-acetic acid (IAA) in the northern Adriatic Sea. In 1990 and 1991, samples from 10 stations were taken and seasonal and regional distributions of IAA were examined. We found IAA in samples collected from Stns 1 \& 2 (September 1990 and August 1991) and from Stn 6 (August 1991). The semiquantitatively estimated IAA concentration was on the order of $10^{-9} \mathrm{M}$. The relationship between the presence of IAA and the mucilage phenomenon was considered.
\end{abstract}

\section{INTRODUCTION}

The increasing process of eutrophication of the northern Adriatic Sea and its consequences make this region extremely interesting for environmental studies. The Adriatic Sea is strongly influenced by the River Po which supplies it with fresh and nutrientenriched water and which causes a high primary productivity level. The non-consumed excess of organic matter sediments to the bottom and decomposes there. During calm and warm weather it leads to almost anoxic conditions in the lower layers of the water column. For many years, and with a certain frequency the eutrophication of the Adriatic Sea has been accompanied by the appearance of mucilaginous aggregates (Degobbis 1989, Andreoli et al. 1990). Recently, the mucilage phenomenon has been observed to an unexpected extent. This fact encouraged many researchers to examine the seasonal and regional variations of different environmental factors which could directly or indirectly influence the overproduction of mucus (Herndl 1988, Pagnotta \& Puddu 1990, Vukadin 1991). Although substantial data concerning this problem has been gathered, its mechanism is not yet clear. According to Herndl \& Peduzzi (1988), the mucilage phenomenon is strictly connected with diatom blooms. These organisms contribute to the formation of amor- phous flocs of marine snow which consist of extracellularly exuded mucus and the attached phytoplankton, zooplankton, bacteria and fecal material. Bacteria utilizing dissolved organic matter may also produce slime and at the same time enlarge the flocs on which they live by a new portion of particulate matter (Biddanda 1988). Under certain hydrographic and meteorological conditions these flocs gather first in filaments and then in larger aggregates called mucilages (Herndl 1988, Stachowitsch 1990). Beside the above factors, some other authors have considered nutrient content and the importance of the N/P ratio in the process of mucilage formation (Rinaldi et al. 1990). The ecological aspect of this problem was described by Herndl (1988). Preliminary chemical characterisation was carried out by Marchetti et al. (1989) and showed that mucus in its organic part was mainly polysaccharide in nature.

The appearance of great amounts of mucus (which is a product of marine organisms' extracellular exudation) could possibly be stimulated by the presence of certain bioactive compounds (vitamins, phytohormones). We showed that in laboratory experiments there exists a clear correlation between the presence of some plant hormones and the increase in mucus production by marine diatoms in culture (Homme \& Mazur 1992a, b)

An auxin-like substance was detected in coastal 
Scottish seawater, and estimated by bioassay as $1.9 \times 10^{-11} \mathrm{M}$ (Bentley 1960). Maruyama et al. (1989) examined the presence of indole-3-acetic acid (IAA) in seawater and marine sediments of Tokyo Bay and Aburatsubo Inlet by high-performance liquid chromatography (HPLC) and enzyme-linked immunosolvent assay (ELISA). They identified this auxin in both of these media, and estimated the IAA content in seawater as 1.2 to $22 \times 10^{-11} \mathrm{M}$ and in marine sediments as $10^{-10}$ to $10^{-6} \mathrm{M}$, depending on season and location.

As far as we know, the presence of IAA in the Adriatic Sea has never been examined before. Here, we give results of our analysis using HPLC and combined gas chromatography - mass spectrometry (GC-MS) methods.

\section{MATERIAL AND METHODS}

Seawater samples. One litre samples of seawater were collected from 10 stations in the northern Adriatic Sea (Fig. 1) during research cruises which took place in February-March, June, July, August, September,

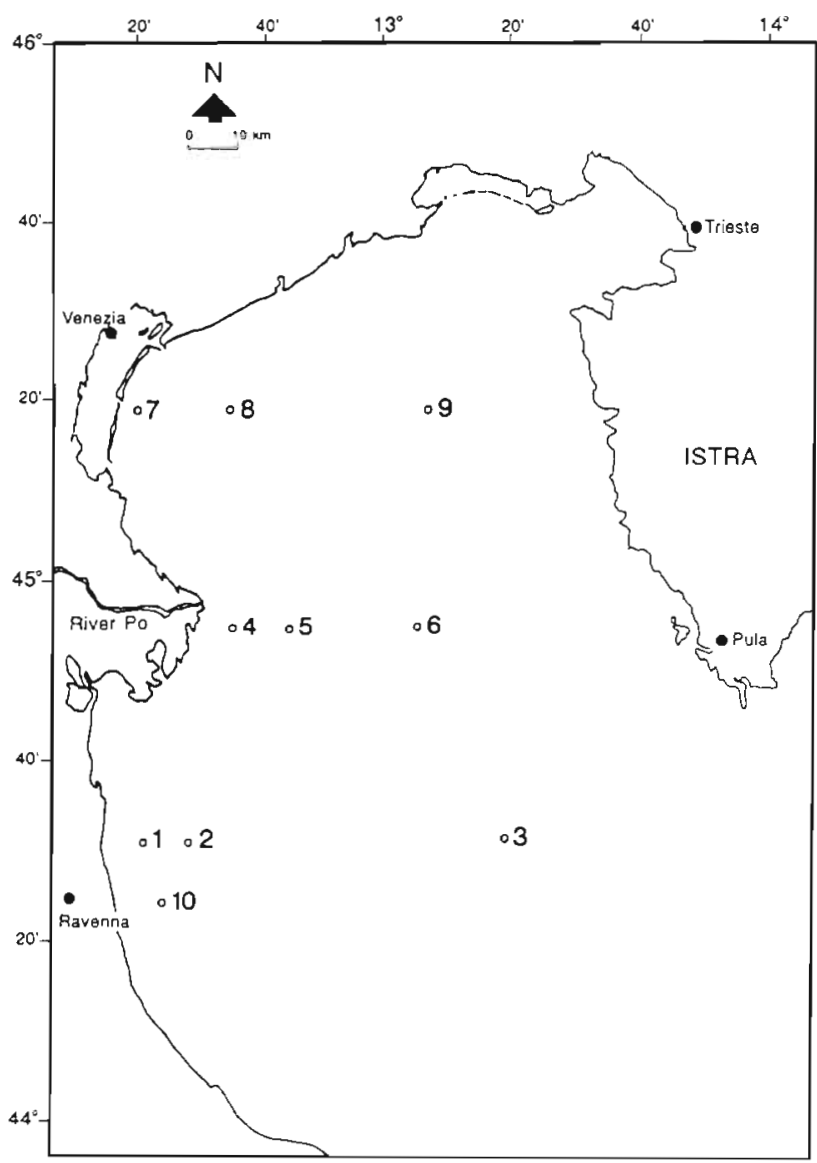

Fig. 1. Location of sampling stations in the northern Adriatic Sea
October and November 1990 and August 1991. Depths at sampling stations were as follows: Stn 1, $15 \mathrm{~m}$; Stn 2, $22 \mathrm{~m} ; \operatorname{Stn} 3,41 \mathrm{~m}_{i} \operatorname{Stn} 4,21 \mathrm{~m}_{\text {; }} \operatorname{Stn}$ 5, $30 \mathrm{~m}_{\text {; }} \operatorname{Stn}$ 6, $33 \mathrm{~m}_{\text {; }}$ Stn 7, $11 \mathrm{~m} ; \operatorname{Stn} 8,16 \mathrm{~m}$; Stn 9, $30 \mathrm{~m} ; \operatorname{Stn} 10,16 \mathrm{~m}$. All samples were mixtures of seawater taken at different depths, from surface to bottom, every $5 \mathrm{~m}$, representing an integrated water-column sample. Samples from Stns 1 \& 2 and from Stns 4 \& 5 were analyzed together. Seawater was filtered through Whatman GF/F glass microfibre filter and stored at $-20^{\circ} \mathrm{C}$ until required.

Concentration column. Instead of time-consuming extractions with organic solvents we used a concentration column with Amberlite XAD-4 resin. Application of this resin to plant hormone analysis was described by Stafford et al. (1984) and Synak et al. (1986). Our preliminary experiments with standards confirmed its excellent yield. Prior to the analysis the $5 \mathrm{~g}$ resin was purified in a Soxhlet apparatus with acetone and methanol for $12 \mathrm{~h}$ each. When transferred to the glass column, it was rinsed with distilled water. Samples of seawater were applied to the resin column which was then washed with $25 \mathrm{ml}$ of distilled water ( 3 bed volumes). The sorbed substances were eluted with $200 \mathrm{ml}$ of methanol, evaporated to dryness and redissolved in $1 \mathrm{ml}$ of methanol.

High-performance liquid chromatography. The methanol solutions obtained after chromatography on Amberlite XAD-4 were analyzed using a HPLC Waters Action Analyzer with a UV detector which operated at a wavelength of $280 \mathrm{~nm}$. The injector was a Rheodyne Model 7125. The Supelcosil LC-18, $3 \times 3$ reversedphase column $(3.3 \mathrm{~cm} \times 4.6 \mathrm{~mm} ; 3 \mu \mathrm{m}$ packing) was selected for the analyses. Samples were analyzed with eluent gradient and isocratically. The elution program was a 15 min convex gradient from 5 to $20 \%$ of acetonitrile in water containing $1 \%$ acetic acid and $1 \mathrm{mM}$ tetrabutylammonium phosphate as ion pair reagent When analyzing isocratically, the mobile phase was $20 \%$ acetonitrile in water containing $1 \%$ acetic acid and $1 \mathrm{mM}$ tetrabutylammonium phosphate. The flow rate was $0.5 \mathrm{ml} \mathrm{min}^{-1}$. All organic solvents were HPLCgrade and water was purified with the Milli-Q Water System.

Those samples analyzed with HPLC which gave retention time peaks corresponding to the IAA (Sigma) standard were subjected to GC-MS analysis

Gas chromatography - mass spectrometry. Samples intended for GC-MS analyses were freeze-dried and silylated with $\mathrm{N}, \mathrm{O}$-bis(trimethylsilyl)-acetamide (BSA, Pierce) at $80^{\circ} \mathrm{C}$ for $30 \mathrm{~min}$. Under these conditions 2 trimethylsilyl (TMS) groups were incorporated into IAA molecules. The GC-MS analyses were performed on a Hewlett-Packard 5890 Series gas chromatograph interfaced to a 5988 Series mass spectrometer with a quadrupole analyzer. We used a $60 \mathrm{~m}$ capillary column 
type SPB-1 with film thickness $1 \mu \mathrm{m}$ and i.d. $0.32 \mathrm{~mm}$ The helium carrier gas flow rate was $0.92 \mathrm{ml} \mathrm{min}^{-1}$. The injection was at $300^{\circ} \mathrm{C}$; oven temperature was $150^{\circ} \mathrm{C}$ at injection and then increased by $10^{\circ} \mathrm{C} \mathrm{min}^{-1}$ to $300^{\circ} \mathrm{C}$. The temperature of the ion source was $200^{\circ} \mathrm{C}$, the electron energy $70 \mathrm{eV}$ and the emission current $300 \mu \mathrm{A}$. Electron impact (EI) spectra and positive chemical ionisation (PCI) spectra with methane as reagent gas were recorded and compared with spectra of a standard analyzed under the same conditions. Additionally, 2 ions characteristic of TMS-IAA spectra, i.e. at $\mathrm{m} / \mathrm{z} 202$ and 319 were monitored using the selected ion monitoring (SIM) technique.

\section{RESULTS}

The studies of the northern Adriatic Sea were carried out from February 1990 until August 1991. In 1990 they revealed the presence of organic aggregates in July only, at Stns 1 \& 2. In 1991 the mucilage phenomenon was widely observed throughout the examined region in August and September.

Seawater samples taken during 8 research cruises from 10 stations in the northern Adriatic Sea were examined. But only in 5 samples was the retention time peak corresponding to the standard IAA found by HPLC analysis: 3 samples from Stns 1 \& 2 collected in July 1990, September 1990 and August 1991, 1 sample from Stns 4 \& 5 collected in March 1990, and 1 sample from Stn 6 collected in August 1991. The identity of retention time with that of authentic IAA, analyzed under the same conditions, was confirmed by isocratic and gradient HPLC analyses. Also coinjection with the standard was applied and at the expected retention time only 1 peak appeared. The amount of substance tentatively identified as IAA was estimated to be on the order of $10^{-9} \mathrm{M}$ based upon a comparison of peak area with that from a known amount of standard. No correction was made for losses during analytical procedures.

In 3 of the 5 above-mentioned samples the presence of IAA was established using the combined GC-MS method with application of the SIM technique. They were 2 samples from Stns 1 \& 2 collected in September 1990 and August 1991, and 1 sample from Stn 6 collected in August 1991. The total ion currents of their TMS-derivatives gave a retention time peak corresponding to that of TMS-IAA (17 min
$10 \mathrm{~s})$. At this retention time the EI mass spectra of the 3 selected samples showed major ions at $\mathrm{m} / \mathrm{z} 319,202$, and 73 (Fig. 2). Sometimes, instead of the molecular ion peak at $\mathrm{m} / \mathrm{z} 319$, the peak appeared at $\mathrm{m} / \mathrm{z} 304$. This M-15 peak is derived from loss of a methyl group by the molecular ion. Also the EI spectrum of authentic TMS-IAA shows the presence of a molecular ion peak at $\mathrm{m} / \mathrm{z} 319$, the base ion peak at $\mathrm{m} / \mathrm{z} 202$ and the nonspecific peak at $\mathrm{m} / \mathrm{z}$ 73, which is typical for all TMSderivatives (Fig. 3).

The applied PCI with methane as reagent gas showed the presence of peaks at $\mathrm{m} / \mathrm{z} 304(27), 320(100)$, $348(11)$ and $360(3)$ in the spectra of the analyzed samples (Fig. 4). The value in parentheses indicates relative intensity of peak. The peaks at $\mathrm{m} / \mathrm{z} 320,348$ and 360 correspond to $\mathrm{MH}^{+}, \mathrm{MC}_{2} \mathrm{H}_{5}{ }^{+}$and $\mathrm{MC}_{3} \mathrm{H}_{5}{ }^{+}$ions respectively. At the same retention time, the same ion peaks were present in PCI spectra of the silylated standard, i.e. at $\mathrm{m} / \mathrm{z}$ 202(25), 304(28), 320(100), 348(11) and 360(3) (Fig. 5). Moreover, the relative intensities of these ions in the examined samples were in good agreement with those of authentic TMS-IAA.

In case the amount of compound was too small to give a full EI spectrum, all 5 samples selected after HPLC were re-run and ions characteristic of TMS-IAA at $\mathrm{m} / \mathrm{z} 202$ and 319 were monitored. The SIM technique confirmed the presence of these ion peaks in 3 samples and at the retention time of the silylated standard. The identity of the selected ion peaks at $\mathrm{m} / \mathrm{z} 202$ and 319 in the spectra of the analyzed samples with those of the standard was additionally confirmed by coinjection with TMS-IAA. Each time only 1 peak ap-

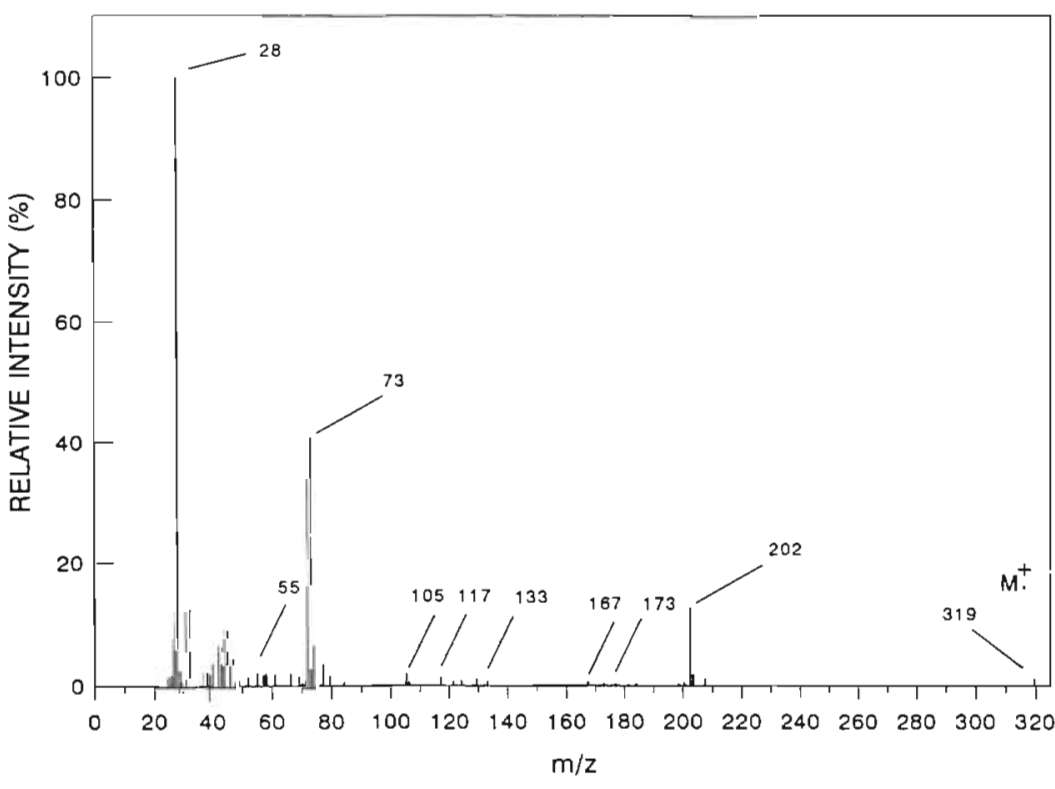

Fig. 2. Electron impact mass spectrum of silylated compound from seawater sample from Stn 6, taken 28 August 1991 


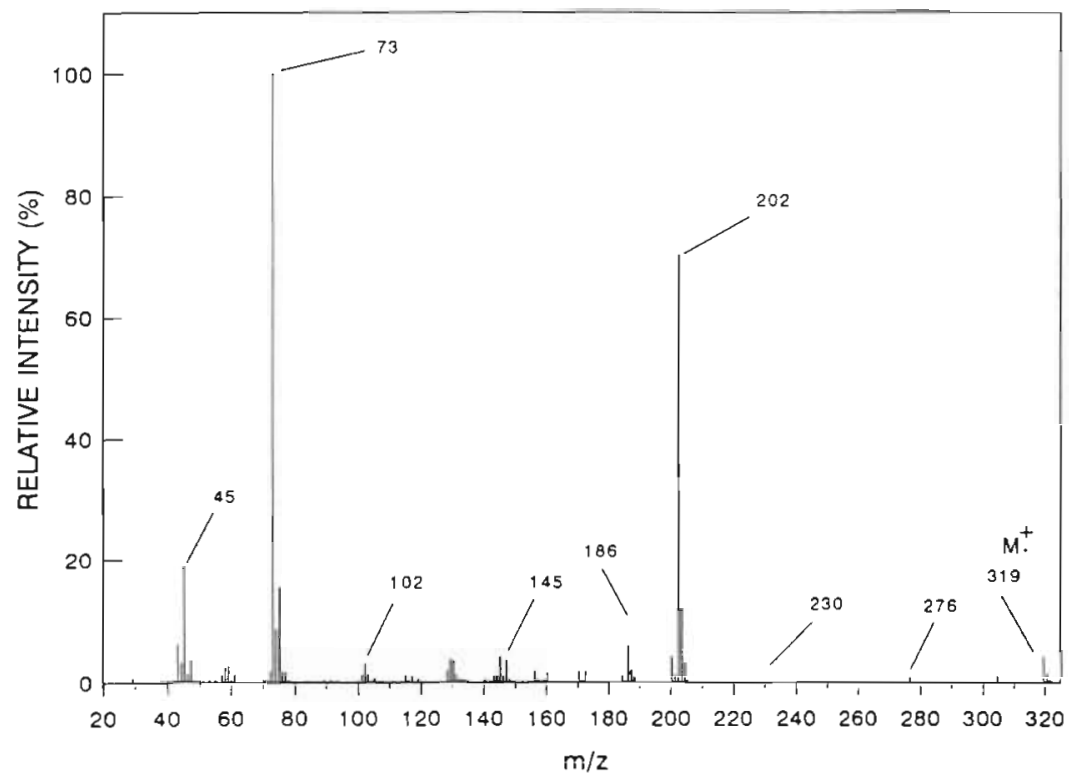

Fig. 3. Electron impact mass spectrum of silylated authentic indole-3-acetic acid

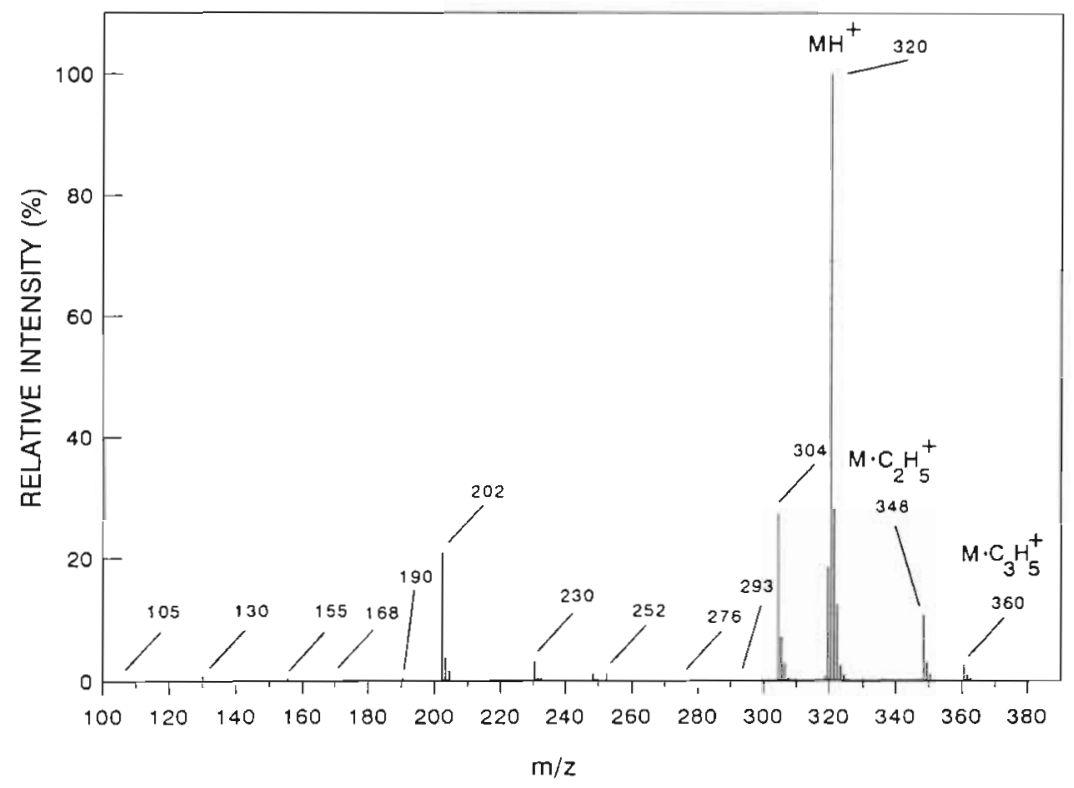

Fig. 4. Positive chemical ionization mass spectrum of silylated compound from seawater sample from Stns $1 \& 2$, taken 26 August 1991

peared at a proper scan and contained contributions from both the standard and the putative TMS-IAA from a sample. No traces of these ion peaks were detected in the remaining samples, i.e. those collected from Stns $1 \& 2$ in July 1990 and from Stns $4 \& 5$ in March 1990.

\section{DISCUSSION}

For the first time the presence of IAA in seawater is confirmed by reversed-phase HPLC and combined
GC-MS methods. It is also the first time that IAA presence is reported in the Adriatic Sea. Results of our analyses indicate the presence of IAA in samples of seawater taken from Stns $1 \& 2$ in September 1990 and August 1991 and from Stn 6 in August 1991. In these samples the IAA concentrations, estimated by comparison of their peak areas with those from a known amount of standard, were about $1 \times 10^{-9} \mathrm{M}$, $3 \times 10^{-9} \mathrm{M}$ and $2 \times 10^{-9} \mathrm{M}$ respectively. These concentrations are 2 orders of magnitude higher than those stated by Bentley (1960) and Maruyama et al. (1989), $1.9 \times 10^{-11} \mathrm{M}$ and 1.2 to $22 \times 10^{-11} \mathrm{M}_{\text {, for }}$ Scottish and Japanese coastal waters respectively. For sample purification we used chromatography on Amberlite XAD-4 resin which showed approximately $100 \%$ recovery. This method is also simple and rapid and therefore it prevents the loss of such a labile compound as IAA. The method of IAA isolation used by Bentley (1960) and Maruyama et al. (1989), based on ether partitioning of methanol extracts, is reported to give a recovery efficiency of between 60 and $76 \%$ (Mousdale et al. 1978). However, differing recoveries of the 2 applied methods are not sufficient to explain this significant difference in detected IAA concentration. It was remarkable that IAA was detected in the same stations 2 years in succession and nearly at the same season: the beginning of September 1990 and the end of August 1991. It would indicate a certain regularity in the processes in the waters of the northern Adriatic Sea which lead to the appearance of IAA or to an increase in its concentration up to the detectable value. It seems to be probable that the rich algal blooms caused by high eutrophication typical of this region are the source of auxin in seawater. IAA could either be exuded by algae or released during decomposition of their cells. However, this hypothesis is still open to question. Some authors believe that IAA is present in algal extracts (Abe et al. 1972, Fries \& Aberg 1978, Jacobs et al. 1985, Sanderson et al. 1987) but it is unclear whether IAA is synthesized by these organisms or by bacteria living in the same environment (Libbert et al. 1966 , 


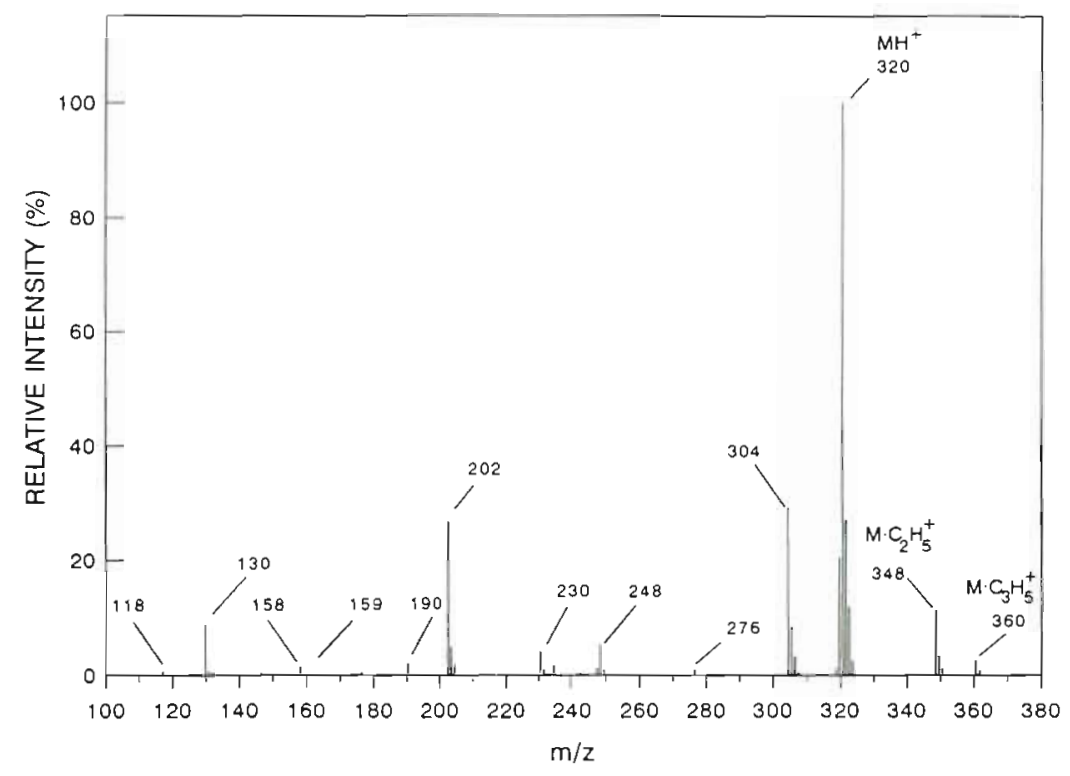

Fig. 5. Positive chemical ionization mass spectrum of silylated authentic indole3-acetic acid

Maruyama et al. 1989) or both. The presence of plant hormones in algal cells and their role in algal development is controversial (Bradley 1991, Evans \& Trewavas 1991). Evans \& Trewavas (1991) claimed that even if algae possess the potential for chemical regulation of development, we do not know if it is endogenous plant growth regulators which influence this process. The answer is difficult, also because most of the experiments were carried out on material taken from natural environments and/or in non-sterile cultures. Maruyama et al. (1989) showed in laboratory experiments that marine bacteria living in sediments contributed significantly to IAA production, especially in the presence of tryptophan or when seaweeds were added to the non-aerated culture. Also, much higher IAA concentration in marine sediments than in overlaying water was estimated by HPLC-ELISA. Therefore, it is possible that after the bloom, algae sink to the bottom of the sea and there decay in low oxygen concentrations. Then, presumably in the presence of marine microorganisms, the tryptophan from algal cells is converted into IAA. Data on the vertical distribution of IAA would probably bring some further information on the origin of this substance in the northern Adriatic Sea.

The main aim of our work was to check whether IAA is present in the Adriatic Sea. However, in the course of these studies, we observed a fact worth considering, that in 1990 Stns $1 \& 2$ were the only places where IAA was detected (the beginning of September) and at the same time the only ones where in that year the mucilages were observed (July). But, in 1991, IAA was detected again at Stns $1 \& 2$ and additionally at Stn 6 . In that year mucilages appeared over a wider area, also at Stns 1, 2 and 6, and were observed simultaneously with IAA (at the end of August). We consider some possible kinds of dependence between the appearance of large amounts of mucus and the already-proved presence of IAA in this region. According to our laboratory experiments IAA at higher concentrations i.e. $10^{-2}$ and $1 \mathrm{mg} \mathrm{l}^{-1}$ causes a significant increase in mucus exudation by marine diatoms in culture (Homme \& Mazur 1992b). Also, in a natural environment, IAA could influence the production of mucus by marine organisms, especially when the detected IAA concentration is higher than in other regions. Another, quite contrary process may also take place. It is known that mucilages - organic aggregates - constitute a matrix for marine microorganisms. These microorganisms could subsequently synthetize IAA using the matrix components as a substratum. Detection of IAA only in water where flocs were present seems to speak for the latter hypothesis.

We think that the phenomenon is complex and probably dependent on different environmental factors. The results already obtained concerning IAA presence and mucus production by algae in the northern Adriatic Sea encourage us to examine this problem further since many questions still remain unanswered.

Acknowledgements. We express our gratitude to Prof. Franco Magno from the University of Padova for his hospitality which enabled us to carry out this work. We are also grateful to Dr Paolo Pastore for his help and advice throughout this study. Thanks to Andrea Boaretto for technical assistance. The GC-MS analyses were done in the Research Centre of EniChem (Marghera) with the valuable help of Dr Paolucci, Dr Pannocchia and his assistant. Financial support was provided by the Commission of the European Communities and Enichem.

\section{LITERATURE CITED}

Abe, H., Uchiyama, M., Sato, R. (1972). Isolation and identification of native auxin in marine algae. Agric. biol. Chem 36: $2259-2260$

Andreoli, C., Giani, M., Homme, E. (1990). Aggregati gelatinosi dell'Adriatico Settentrionale: studi biologici e chimico-fisici. Atti XVIII Conv. naz. Ambiente e Risorse (Bressanone): 321-331

Bentley, J. A. (1960). Plant hormones in marine phytoplankton, zooplankton and seawater. J. mar. biol. Ass. U.K. 39: $433-444$

Biddanda, B. A. (1988). Microbial aggregation and degradation of phytoplankton-derived detritus in seawater. II. Microbial metabolism. Mar. Ecol. Prog. Ser. 42: 89-95 
Bradley, P. M. (1991). Plant hormones do have a role in controlling growth and development of algae. J. Phycol. 27: $317-321$

Degobbis, D. (1989). Increased eutrophication of the Northern Adriatic Sea. Mar. Pollut. Bull. 20: 452-457

Evans, L. V., Trewavas, A. J. (1991). Is algal development controlled by plant growth substances? J. Phycol. 27: 322-326

Fries, L., Aberg, S. (1978). Morphogenetic effects of phenylacetic and p-OH-phenylacetic acid on the green alga Enteromorpha compressa (L.) Grev. in axenic culture. Z. PflPhysiol. 88; 383-388

Herndl, G. J. (1988). Ecology of amorphous aggregations (marine snow) in the Northern Adriatic Sea. Mar. Ecol. Prog. Ser. 48: 265-275

Herndl, G. J., Peduzzi, P. (1988). The ecology of amorphous aggregation (marine snow) in the Northern Adriatic Sea. General consideration. P.S.Z.N. I: Mar. Ecol. 9: $79-90$

Homme, E., Mazur, H. (1992a). Ormoni vegetali e formazione delle sostanze mucillaginose nell'ambiente marino. Ambiente Risorse Salute 5: 7-11

Homme, E., Mazur, H. (1992b). Indagine sperimentale sul ruolo degli ormoni vegetali sull'essudazione delle sostanze mucillaginose dalle microalghe marine. Ambiente Risorse Salute 6: 8-15

Jacobs, W. P., Falkenstein, K., Hamilton, R. H. (1985). Nature and amount of auxin in algae. Plant Physiol. 78: $844-848$

Libbert, E., Wichner, S., Schiewer, U., Risch, H., Kaiser, W. (1966). The influence of epiphytic bacteria on auxin metabolism. Planta 68: 327-334

Marchetti, R., Iacomini, M., Torri, G., Focher, B. (1989). Caratterizzazione preliminare degli essudati di origine fit-

This article was submitted to the editor oplanctonica raccolti in Adriatico nell'estate 1989. AcquaAria 8: 883-887

Maruyama, A., Maeda, M., Simidu, U. (1989). Microbial production of auxin indole-3-acetic acid in marine sediments. Mar. Ecol. Prog. Ser. 58: 69-75

Mousdale, D. M. A.. Butcher, D. N., Powell, R. G. (1978). Spectrophotofluorimetric methods of determining indole3-acetic acid. In: Hillman, J. R. (ed.) Isolation of plant growth substances. Cambridge University Press, Cambridge, p. 27-39

Pagnotta, R., Puddu, A. (1990). L'eutrofizzazione delle acque in Italia. Inquinamento $7 / 8: 9-18$

Rinaldi, A., Montanari, G., Ghetti, A., Ferrari, C. R., Penna, N (1990). Presenza di materiale mucillaginoso nell'Adriatico Nord-Occidentale negli anni 1988 e 1989. Dinamica dei processi di formazione, di diffusione e di disposizione. Acqua Aria 7/8: 561-567

Sanderson, K. J., Jameson, P. E., Zabkiewicz, J. A. (1987). Auxin in a seaweed extract: identification and quantitation of indole-3-acetic acid by gas chromatography-mass Spectrometry. Plant Physiol. 129: 363-367

Stachowitsch, M., Fanuco, N., Richter, M. (1990). Mucus aggregates in the Adriatic Sea: an overview of stages and occurrences. P.S.Z.N. I: Mar. Ecol. 11: 327-350

Stafford, A. E., Kunhle, J. A., Corse, J., Hautala, E. (1984). Isolation and purification of plant hormones by XAD-2 column chromatography. J. Chromatogr. 294: 483-488

Synak, R., Zarebska, I., Kentzer, T. (1986). The use of a resin adsorbent to isolate cytokinins from sea water. Biol. Plant. 28: $412-416$

Vukadin, I. (1991). Hydrographic and biological aspects of algal bloom in the Adriatic Sea in 1988. Toxic. environ. Chem. 31-32: 265-274

Manuscript first received: October 13, 1992

Revised version accepted: April 15, 1993 